\title{
Impact of root herbivory by insect larvae on soil microbial communities
}

\author{
Susan J. Grayston ${ }^{\mathrm{a} *}$, Lorna A. Dawson ${ }^{\mathrm{a}}$, Amy M. Treonis ${ }^{\mathrm{a}}$, Philip J. Murray ${ }^{\mathrm{b}}$, \\ Jasmine Ross ${ }^{\mathrm{a}}$, Eileen J. Reid ${ }^{\mathrm{a}}$, Ruth MacDougall ${ }^{\mathrm{a}}$ \\ a Macaulay Land Use Research Institute, Craigiebuckler, Aberdeen AB15 8QH, Scotland, UK \\ ${ }^{\mathrm{b}}$ Institute of Grassland and Environmental Research, North Wyke Research Station, \\ Okehampton, Devon EX20 2SB, UK
}

Received 14 August 2000; accepted 13 April 2001

\begin{abstract}
Bentgrass (Agrostis capillaris) and clover (Trifolium repens) were grown as pure swards and mixtures in pots containing soil from the NERC Soil Biodiversity field site located in Scotland. Six weeks after plant establishment leatherjacket larvae (Tipula paludosa) were added at field density to half the pots and the impacts of their feeding on plant shoot and root biomass and soil microbial communities was determined after 10 days. Plate counts and community level physiological profiles (CLPP) were used to characterise the microbial communities. Larval herbivory had a significant negative effect on shoot growth of both grass and clover and root biomass of grass. In mixed swards, larvae preferentially fed on clover. Soil microbial community structure was altered in the presence of larvae with populations of pseudomonads being significantly increased. These community differences may be attributed to increased quantity and qualitative changes in carbon flux to the soil as a result of root herbivory, as indicated by differences in the CLPPs of microbial communities in the presence and absence of larvae. This was mainly due to increased utilisation of some sugars, carboxylic and amino acids in the presence of larvae. (C) 2001 Éditions scientifiques et médicales Elsevier SAS
\end{abstract}

Biolog / community level physiological profiles / grasses / insect root herbivores / soil microorganisms

\section{INTRODUCTION}

The increasing emphasis on low input extensive agriculture means that achieving sustainable plant growth will depend on devising strategies to maximise the use of soil nutrient resources. In such systems, which include upland grasslands, the soil microbial biomass is critical in regulating soil ecosystem level processes, such as nutrient cycling [12]. Therefore, it is vital to understand the factors that influence its structure and activity. Root herbivory by insect larvae will change soil carbon and nutrient flows and is, therefore, likely to have a major impact on soil microbial communities and subsequently nutrient cycling. However, despite the importance of microbial processes in these systems, few studies have linked them to root herbivory. The root feeding leatherjacket larvae (Tipula paludosa) are important pests of grasslands and cereal crops [5]. Although much work has been done on the impact of these larvae on yield reduction $[1.2 .14]$, the impact on microbial communities has not been evaluated.

Community level physiological profiles (CLPP) (Bi$\operatorname{olog}^{\circledR}$ ) have shown their potential as an ecologically

*Correspondence and reprints: fax: +44-1224-311556.

E-mail address: s.grayston@macaulay.ac.uk (S.J. Grayston). relevant method to characterise microbial communities from the rhizosphere of different plant species 7 2. 10]. The technique measures utilisation of a variety of carbon compounds and is therefore a meaningful assay of communities because carbon is a major factor governing microbial growth in soil [17].

The aim of this study was to determine the impact of root herbivory by T. paludosa on microbial community structure in the rhizosphere of Agrostis capillaris and Trifolium repens, using selective plating techniques and CLPP. The hypothesis to be tested was that larval root herbivory would change the microbial community as a consequence of increased root detritus and exudation and this would be reflected in a difference in CLPP between these communities.

\section{MATERIALS AND METHODS}

\subsection{Experimental design}

Soil (Sourhope series; brown podzol; Tot C 101 $\mathrm{g} \cdot \mathrm{kg}^{-1}$, Tot N $7.7 \mathrm{~g} \cdot \mathrm{kg}^{-1}$ ) was collected from a field of permanent grassland at Sourhope Research Station $\left(55^{\circ} 28^{\prime} 30^{\prime \prime} \mathrm{N} / 2^{\circ} 14^{\prime} \mathrm{W}\right)$ located in the Borders of Scotland. The soil was sieved $(<6 \mathrm{~mm})$ then used to fill $23 \mathrm{~cm}$ diameter pots to a depth of $20 \mathrm{~cm}$. Pots were sown with seeds of either $A$. capillaris (bentgrass), $T$. 
repens (white clover) or a mixture of both at a density of $25 \mathrm{~g} \cdot \mathrm{m}^{-2}$. Six replicates of each treatment were grown in the greenhouse until sward establishment $(6$ weeks) and watered daily to excess. After 6 weeks 20 T. paludosa (Meigen, 1830) larvae (fourth instar), collected from the same field site, were added to each of three replicate pots of each sward type (density 482 larvae $\cdot \mathrm{m}^{-2}$ ). The pots were harvested 10 days after introduction of larvae.

\subsection{Plant biomass analyses}

Shoots were removed by clipping at soil level and shoots of $A$. capillaris and $T$. repens were separated from the mixed swards. Roots were removed by dry sieving and manual removal. Roots from mixed swards could not be separated into species due to their similarities. Shoots and roots were weighed, oven dried at $80^{\circ} \mathrm{C}$ for $48 \mathrm{~h}$ and reweighed.

\subsection{Microbial community analyses}

Microbial communities were extracted from soil by shaking $10 \mathrm{~g}$ of soil in $100 \mathrm{~mL}$ of $1 / 4$ strength Ringers solution (Oxoid) for $10 \mathrm{~min}$, on a wrist action shaker. After ten-fold serial dilution in Ringers, suspensions $(0.1 \mathrm{~mL})$ were spread in duplicate on the following media. Tryptone Soy agar (1/10 strength, Oxoid) plus cycloheximide $\left(50 \mathrm{mg} \cdot \mathrm{L}^{-1}\right)$ to enumerate bacteria, Pseudomonas isolation agar (Oxoid) selective for pseudomonads and Czapek-Dox agar (Oxoid) plus ampicillin $\left(10 \mathrm{mg} \cdot \mathrm{L}^{-1}\right)$, streptomycin and tetracycline $\left(50 \mathrm{mg} \cdot \mathrm{L}^{-1}\right)$ for enumeration of fungi. Plates were incubated at $25^{\circ} \mathrm{C}$ and colonies counted weekly until no new growth appeared.

Biolog ${ }^{\circledR}$ GN microplates (Biolog Inc., Hayward, CA, USA), which contain 95 different carbon sources, were used together with exudate profile microplates, prepared using Biolog ${ }^{\circledR}$ MT plates, [3] to construct community level physiological profiles (CLPP) of the microbial communities. A $50 \mathrm{~mL}$ aliquot of the $10^{-4}$ dilution of the same rhizosphere soil samples used in the enumeration of culturable microorganisms was centrifuged at $2000 \mathrm{rpm}$ for $10 \mathrm{~min}$ to separate soil and minimise addition of soil or root derived carbon into the system. A $0.15 \mathrm{~mL}$ aliquot of each sample was dispensed into each well of the GN and exudate plates. The plates were incubated at $15^{\circ} \mathrm{C}$ for 5 days and colour development (carbon utilisation) measured as absorbance at $590 \mathrm{~nm}$ every $24 \mathrm{~h}$ using a microplate reader (Vmax, Molecular Devices, Oxford, UK).

\subsection{Statistical analyses}

All plant biomass data was untransformed, with the exception of the shoot data from the mixed swards that was square root transformed, prior to ANOVA (Genstat 5.4, NAG Ltd., Oxford, UK). Microbial population data was log transformed prior to ANOVA. For the CLPP data the average well colour development (AWCD) of all 125 carbon sources for each sample were calculated and used to transform individual well values to eliminate variation in well colour deyelopment caused by different cell densities $[6,8]$. The AWCD of different substrate groups (sugars, oligosaccharides, carboxylic acids, acidic amino acids, basic amino acids, neutral amino acids, amides, phenolic acids, alcohols, N-heterocyclic-N, long chain aliphatic acids and all compounds) was calculated prior to performing ANOVA. The CLPP data from each incubation time were also analysed by canonical variate analysis (CVA) (Genstat 5.3) to differentiate samples based on their overall patterns of carbon utilisation and to identify the carbon sources most responsible for the discrimination.

\section{RESULTS}

\subsection{Plant biomass}

In the single species pots larvae significantly $(F<0.001,2$ d.f.) reduced the shoot biomass of both $A$. capillaris and $T$. repens (table $)$. In the mixed sward only, $T$. repens shoot biomass was significantly reduced in the presence of larvae $(F=0.028)$ (table - ). The root biomass of both species was reduced in pots with larvae, but this was only significant $(F<0.001)$ for A. capillaris in the single species pots table d).

\subsection{Microbial communities}

Numbers of total bacteria tended to be increased in the presence of larvae in pots sown with A. capillaris and the A. capillaris/T. repens mixture, although these increases were not significant. Numbers of pseudomonads, however, were significantly $(F<0.001$, 2 d.f.) increased in all treatments in the presence of larvae (figure - ]). Populations of yeasts and fungi were not significantly affected by any treatment (data not

Table I. Shoot and root biomass of Agrostis capillaris and Trifolium repens after10 days in the presence and absence of Tipula paludosa larvae.

\begin{tabular}{lll}
\hline Plant & \multicolumn{2}{l}{ Shoot biomass g.pot ${ }^{-1}$} \\
\cline { 2 - 3 } & - larvae & + larvae \\
\hline Agrostis capillaris (alone) & $3.31^{\mathrm{c}}$ & $1.79^{\mathrm{b}}$ \\
Trifolium repens (alone) & $1.64^{\mathrm{b}}$ & $0.04^{\mathrm{a}}$ \\
Agrostis capillaris (mixture) & $3.02^{\mathrm{c}}$ & $2.42^{\mathrm{c}}$ \\
Trifolium repens (mixture) & $0.44^{\mathrm{b}}$ & $0.12^{\mathrm{a}}$ \\
\hline Plant & \multicolumn{2}{l}{ Root biomass g.pot ${ }^{-1}$} \\
\cline { 2 - 3 } & - larvae & + larvae \\
\hline Agrostis capillaris & $1.92^{\mathrm{b}}$ & $0.96^{\mathrm{c}}$ \\
Trifolium repens & $0.31^{\mathrm{a}}$ & $0.17^{\mathrm{a}}$ \\
Agrostis capillaris \& Trifolium repens & $1.26^{\mathrm{b}}$ & $1.03^{\mathrm{b}}$ \\
\hline
\end{tabular}

Values are means of 3 replicate samples ( 2 d.f). Values followed by the same letter are not significantly different $(P<0.05)$. 


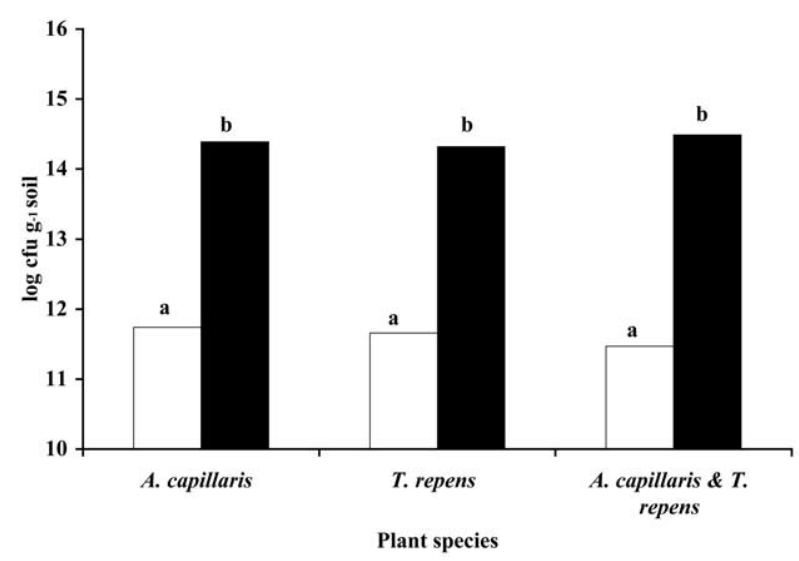

Figure 1. Populations of pseudomonads in the rhizosphere of Agrostis capillaris, Trifolium repens and A. capillaris/T. repens mixtures in the presence and absence of Tipula paludosa. (Values are the means of three replicate samples. Bars with the same letter are not significantly different $P<0.05)$.

shown). The CLPP of the microbial communities showed that, when comparing pots containing the same plant species, microorganisms from pots containing larvae had significantly greater utilisation of all groups of carbon compounds, except for phenolic and long chain aliphatic acids, than those from the same swards without larvae (table $I$ ). CVA results presented are those after $72 \mathrm{~h}$ of incubation because this gave the best discrimination amongst treatments. CVA clearly differentiated the samples from pots with and without larvae on canonical variate (CV) 1 (figure 2). Analysis of the loadings of the carbon sources on this CV indicated that in the presence of larvae some sugars (arabinose, galactose, maltose), carboxylic (tartaric, malic, oxalic) and amino acids (lysine, serine) were mainly responsible for the discrimination.

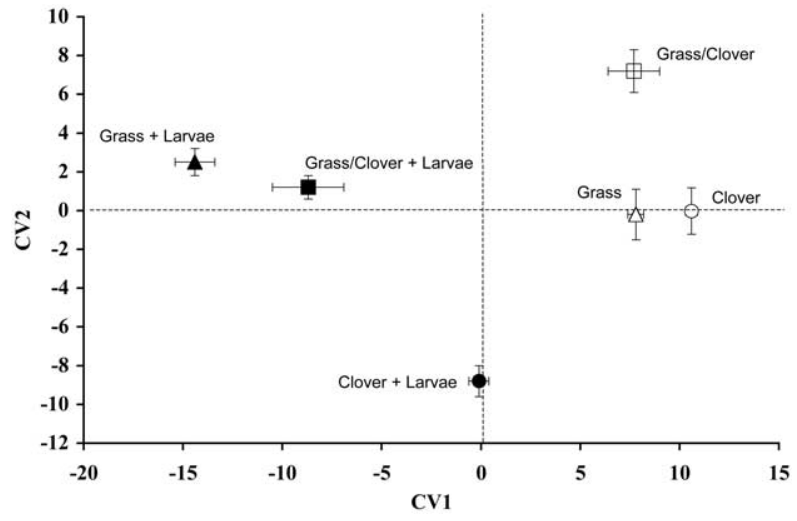

Figure 2. Canonical variate scores of soil samples based on CLPP of microbial communities from the rhizosphere of Agrostis capillaris $(\mathbf{\Delta})$, Trifolium repens $(\bullet)$ and $A$. capillaris/T. repens $(\mathbf{\square})$ mixtures in the presence (solid symbols) and absence (open symbols) of Tipula paludosa. Values are for $72 \mathrm{~h}$ incubation. Bars represent standard deviation.

\section{DISCUSSION}

Herbivory by $T$. paludosa significantly reduced the shoot biomass of both $A$. capillaris and T. repens and the root biomass of $A$. capillaris, when grown in monocultures. In mixed swards T. paludosa herbivory only reduced $T$. repens shoot biomass, suggesting A. capillaris may pe less nutritious to T. paludosa. Ramsell et al [15] showed that T. paludosa larvae preferred to graze on Lolium perenne than Rumex obtusifolius, significantly reducing $L$. perenne root biomass in monocultures and mixtures. However, grazed $L$. perenne was found to be a stronger competitor of $R$ obtusifolius, due to enhanced shoot growth rates [15] These studies suggest that differential shoot and root grazing in mixtures will have important

Table II. Average well colour development (utilisation) of the main groups of carbon compounds in the Biolog GN and exudate plates by microbial communities from the rhizosphere of Agrostis capillaris and Trifolium repens in the presence and absence of Tipula paludosa larvae.

\begin{tabular}{|c|c|c|c|c|c|c|c|}
\hline Carbon compounds & A. capillaris & $\begin{array}{l}\text { T. repens } \\
\text { - larvae }\end{array}$ & $\begin{array}{l}\text { A. capillaris } \\
\& \text { T. repens }\end{array}$ & A. capillaris & $\begin{array}{l}\text { T. repens } \\
\text { + larvae }\end{array}$ & $\begin{array}{l}\text { A. capillaris } \\
\& \text { T. repens }\end{array}$ & $F$ values \\
\hline All & $0.091^{\mathrm{a}}$ & $0.094^{\mathrm{a}}$ & $0.074^{\mathrm{a}}$ & $0.284^{\mathrm{b}}$ & $0.283^{\mathrm{b}}$ & $0.248^{\mathrm{b}}$ & 0.003 \\
\hline Sugars & $0.042^{\mathrm{a}}$ & $0.066^{\mathrm{a}}$ & $0.039^{\mathrm{a}}$ & $0.362^{\mathrm{b}}$ & $0.324^{\mathrm{b}}$ & $0.272^{\mathrm{b}}$ & $<0.001$ \\
\hline Oligosaccharides & $0.045^{\mathrm{a}}$ & $0.050^{\mathrm{a}}$ & $0.045^{\mathrm{a}}$ & $0.442^{\mathrm{b}}$ & $0.432^{\mathrm{b}}$ & $0.337^{\mathrm{b}}$ & $<0.001$ \\
\hline Alcohols & $0.079^{\mathrm{a}}$ & $0.083^{\mathrm{a}}$ & $0.090^{\mathrm{a}}$ & $0.385^{\mathrm{b}}$ & $0.358^{\mathrm{b}}$ & $0.273^{\mathrm{ab}}$ & 0.004 \\
\hline Carboxylic acids & $0.125^{\mathrm{ab}}$ & $0.122^{\mathrm{ab}}$ & $0.096^{\mathrm{a}}$ & $0.286^{\mathrm{c}}$ & $0.293^{\mathrm{c}}$ & $0.240^{\mathrm{b}}$ & 0.022 \\
\hline Acidic amino acids & $0.115^{\mathrm{a}}$ & $0.142^{\mathrm{a}}$ & $0.133^{\mathrm{a}}$ & $0.434^{\mathrm{b}}$ & $0.424^{\mathrm{b}}$ & $0.393^{\mathrm{b}}$ & 0.012 \\
\hline Basic amino acids & $0.154^{\mathrm{abc}}$ & $0.134^{\mathrm{ab}}$ & $0.091^{\mathrm{a}}$ & $0.300^{\mathrm{bc}}$ & $0.340^{\mathrm{c}}$ & $0.307^{\mathrm{bc}}$ & 0.034 \\
\hline Neutral amino acids & $0.075^{\mathrm{a}}$ & $0.074^{\mathrm{a}}$ & $0.044^{\mathrm{a}}$ & $0.286^{\mathrm{b}}$ & $0.245^{\mathrm{b}}$ & $0.263^{\mathrm{b}}$ & 0.003 \\
\hline Heterocyclic N & $0.079^{\mathrm{a}}$ & $0.138^{\mathrm{ab}}$ & $0.078^{\mathrm{a}}$ & $0.328^{\mathrm{bc}}$ & $0.377^{\mathrm{c}}$ & $0.297^{\mathrm{bc}}$ & 0.013 \\
\hline Amides & $0.030^{\mathrm{a}}$ & $0.047^{\mathrm{ab}}$ & $0.041^{\mathrm{ab}}$ & $0.116^{\mathrm{bc}}$ & $0.146^{\mathrm{c}}$ & $0.151^{\mathrm{c}}$ & 0.015 \\
\hline Phenolics & $0.100^{\mathrm{ab}}$ & $0.095^{\mathrm{ab}}$ & $0.074^{\mathrm{a}}$ & $0.125^{\mathrm{ab}}$ & $0.136^{\mathrm{b}}$ & $0.147^{\mathrm{b}}$ & 0.093 \\
\hline Long chain aliphatics & $0.108^{\mathrm{a}}$ & $0.100^{\mathrm{a}}$ & $0.099^{\mathrm{a}}$ & $0.147^{\mathrm{a}}$ & $0.154^{\mathrm{a}}$ & $0.163^{\mathrm{a}}$ & 0.146 \\
\hline
\end{tabular}

Values are means of 3 replicate samples. Values followed by the same letter are not significantly different. 
consequences for plant competition and community composition in grasslands.

Soil microbial community structure and function was altered in the presence of larvae with significantly higher populations of pseudomonads and a change in metabolic profiles of the microbial communities from pots with T. paludosa. Denton et al. [4] showed that root herbivory by clover cyst nematodes significantly increased soil microbial biomass. They hypothesised that nematode herbivory increased root exudation, as shown by Yeates et al [18], although they found no change in microbial community structure. Increased root exudation tends to increase bacterial abundance in soil [10_11]. The increase in Pseudomonas species, in this study, is not surprising as they are a nutritionally diverse group of bacteria, have a higher growth rate in soil than other species and there is increasing evidence of their selective stimulation in the rhizosphere of a range of plant species $[10,13]$ The results from this study suggest that root herbivory by $T$. paludosa may increase root exudation and change the character of compounds released because the metabolic profiles of the microorganisms from these treatments were different. In addition, release of larval excrement may also affect the microbial communities, leading to a change in their metabolic profiles. Changes in CLPP due to larvae were mainly due to differences in sugars, carboxylic and amino acid usage. This suggests larval herbivory may increase release of these compounds from roots, or alternately, they may be contained in larval excrement, which then selects for microorganisms capable of utilising these substrates. Studies are currently being undertaken to characterise root exudates from pasture plants subject to $T$. paludosa herbivory [16] In addition, increased detrital input to the soil, as a result of root severance will impact on the microbial community. This data clearly shows that belowground herbivory changes the structure of the soil microbial community. These changes are likely to impact on nutrient cycling and availability, and therefore have important consequences for pasture management and productivity. Future research will investigate the mechanisms involved in these responses.

Acknowledgements. NERC and SEERAD are acknowledged for funding this research.

\section{REFERENCES}

[1] Blackshaw R.P., The impact of leatherjackets on grass yield, Grass For. Sci. 39 (1984) 339-344.

[2] Brown V.K., Gange A.C., Insect herbivory belowground, in: Begon M., Fitter A.H., MacFadyen A. (Eds.), Advances in Ecological Research, Vol. 20, Academic Press, New York, 1990, pp. 1-58.

[3] Campbell C.D., Grayston S.J., Hirst D.J., Use of rhizosphere carbon sources in sole carbon utilisation tests to discriminate soil microbial communities, J. Microbiol. Meth. 30 (1997) 33-41.
[4] Denton C.S., Bardgett R.D., Cook R., Hobbs P.J., Low amounts of root herbivory positively influence the rhizosphere microbial community in a temperate grassland soil, Soil Biol. Biochem. 31 (1999) $155-165$.

[5] French N., Nichols D.B.R., Wright A.J., Yield response of improved upland pasture to the control of leatherjackets under increasing rates of nitrogen, Grass For. Sci. 45 (1990) 99-102.

[6] Garland J.L., Analytical approaches to the characterisation of samples of microbial communities using patterns of potential C source utilisation, Soil Biol. Biochem. 28 (1996) 213-221.

[7] Garland J.L., Patterns of potential C source utilisation by rhizosphere communities, Soil Biol. Biochem. 28 (1996) 223-230.

[8] Garland J.L., Mills A.L., Classification and characterisation of heterotrophic microbial communities on the basis of patterns of community-level-sole-carbonsource utilisation, Appl. Environ. Microbiol. 57 (1991) 2351-2359.

[9] Grayston S.J., Campbell C.D., Functional biodiversity of microbial communities in the rhizosphere of hybrid larch (Larix eurolepis) and Sitka spruce (Picea sitchensis), Tree Physiol. 16 (1996) 1031-1038.

[10] Grayston S.J., Wang S., Campbell C.D., Edwards A.C., Selective influence of plant species on microbial diversity in the rhizosphere, Soil Biol. Biochem. 30 (1998) 369-378.

[11] Grayston S.J., Griffith G.S., Mawdsley J.L., Campbell C.D., Bardgett R.D., Accounting for variability in soil microbial communities of temperate upland grassland ecosystems, Soil Biol. Biochem. 33 (2001) 533-551.

[12] Lee K.E., Pankhurst C.E., Soil organisms and sustainable productivity, J. Soil Res. 30 (1992) 855-892.

[13] Marilley L., Aragno M., Phylogenetic diversity of bacterial communities differing in degree of proximity to Lolium perenne and Trifolium repens roots, Appl. Soil Ecol. 13 (1999) 127-136.

[14] Murray P.J., Hatch D.J., Cliquet J.B., Impact of insect root herbivory on the growth, nitrogen and carbon content of white clover (Trifolium repens L.) seedlings, Can. J. Bot. 74 (1996) 1591-1595.

[15] Ramsell J., Malloch A.J.C., Whittaker J.B., When grazed by Tipula paludosa, Lolium perenne is a stronger competitor of Rumex obtusifolius, J. Ecol. 81 (1993) 777-786.

[16] Treonis A.M., Grayston S.J., Murray P.J., Belowground herbivory: The effects of macroinvertebrate root feeding on root exudation and soil microbial communities in grass and clover swards. Abstracts XIII International Colloquium on Soil Zoology, Ceske Budejovice, Czech Republic, August, 2000.

[17] Wardle D.A., A comparative assessment of factors which influence microbial biomass carbon and nitrogen levels in soils, Biol. Rev. 67 (1992) 321-358.

[18] Yeates G.W., Saggar S., Denton C.S., Mercer C.F., Impact of clover cyst nematode (Heterodera trifolii) infection on soil microbial activity in the rhizosphere of white clover (Trifolium repens): a pulse labelling experiment, Nematologia 44 (1998) 81-90. 